\title{
THE RELATIONSHIP BETWEEN INTERFERON AND VIRUS VIRULENCE IN INFLUENZA VIRUS INFEC- TIONS OF THE MOUSE
}

\author{
C. McLaren and C. W. Potter
}

\begin{abstract}
Department of Medicine, University of Sheffield Virus Research Laboratory, Lodge Moor Hospital, Sheffield and Department of Medical Microbiology, University of Sheffield, Sheffield
\end{abstract}

THERE have been many attempts to explain the virulence of viruses on the basis of their sensitivity to interferon or their ability to induce interferon in infected cells.

Enders (1962) and De Maeyer and Enders (1965) observed that an attenuated strain of measles virus induced larger amounts of interferon than did a virulent strain, but considered that the poorer growth of the attenuated strain was probably not due to the increased production of interferon. Ruiz-Gomez and Isaacs (1963a) studied a number of different viruses and reported that the more virulent ones induced the least amounts of interferon. Similar results were obtained for strains of Semliki Forest, measles and Japanese encephalitis viruses (Finter, 1964; Mirchamsy and Rapp, 1969; Rokutanda, 1969). Vilček (1964), however, found that the amount of interferon produced in mice infected with Sindbis virus was directly related to virus multiplication and he concluded that interferon formation was more probably a secondary response to, rather than a determining factor in, virus replication. Experiments with influenza virus (Link, Blašković and Raus, 1965), Mengo virus (Campbell and Colter, 1967), Sindbis virus (Postic et al., 1969) and Newcastle disease virus (Lomniczi, 1970) have also shown that virulence is not necessarily related to poor induction of interferon.

The results obtained by different workers who have attempted to relate virulence to the sensitivity of the viruses to inhibition by interferon have also been contradictory. RuizGomez and Isaacs (1963b), in studies of arboviruses, myxoviruses and poxviruses, found that, with some exceptions, sensitivity to interferon was inversely related to virulence. Similar results have been reported for strains of foot-and-mouth disease virus (Sellers, 1963) and Semliki Forest virus (Finter, 1964). On the other hand, Campbell and Colter found that three variants of Mengo virus which possessed different degrees of virulence for mice had the same sensitivity to interferon; Rokutanda had similar findings with strains of Japanese encephalitis virus.

The present study compares the virulence of influenza viruses for mice with the amount of interferon induced by them in the lungs of infected mice and with their in-vitro sensitivity to inhibition by interferon. The findings do not agree with the theory that virus virulence is determined by the properties of poor induction of interferon and low sensitivity to the inhibitory action of interferon, but indicate rather that the amount of interferon induced is determined by the degree of virus replication.

\section{MATERIALS AND METHODS}

Virus strains

The $A_{0} /$ WSN (HON1) parent strain of influenza virus and a number of temperaturesensitive (ts) mutants derived from it by 5 -fluorouracil treatment were obtained, as lyophilised 
preparations, from Dr J. S. Mackenzie, Animal Virus Centre, Pirbright, Surrey (Mackenzie, 1969,1970 ). Seed virus pools were prepared by inoculating diluted, reconstituted preparations into the allantoic cavity of 9-day-old embryonated hen's eggs. After incubating at $36^{\circ} \mathrm{C}$ for $48 \mathrm{hr}\left(\mathrm{A}_{0} / \mathrm{WSN}\right)$ or at $31^{\circ} \mathrm{C}$ for $72 \mathrm{hr}$ (ts mutants), the infected allantoic fluids were harvested and stored at $-70^{\circ} \mathrm{C}$. Stock viruses for experimental use were grown from the seed pools and stored in the same way. The ability of the ts mutants to produce plaques in chick embryo fibroblasts at $36^{\circ} \mathrm{C}$ but not at $39^{\circ} \mathrm{C}$, as described by Mackenzie (1970), was confirmed. The $\mathrm{A}_{0} / \mathrm{WSN}$ parent strain grew readily at both temperatures.

The other influenza virus strains studied were in current use in this laboratory. Strain $\mathrm{A}_{0} / \mathrm{NWS}$ (HON1) resembles $\mathrm{A}_{0} / \mathrm{WSN}$ (HON1) in that both are neurovirulent strains derived from $A_{0} / W S(H O N 1)$. Strains $X 7$ (HON2) and $X 9$ (H2N1) are recombinants derived from $\mathrm{A}_{0} / \mathrm{NWS}$ and $\mathrm{A}_{2} / \mathrm{Jap} / 305 / 57$ (H2N2) (Kilbourne et al., 1967). Strain $\mathrm{A}_{2} /$ Singapore/1/57 (H2N2) had previously been adapted to growth in the mouse by serial mouse-lung passage. All these viruses, with the exception of $\mathrm{A}_{0} / \mathrm{WSN}$, were purified by a double cycle of plaquing on rhesus monkey kidney cell cultures. Stock pools were then prepared in hen's eggs, as already described for $\mathrm{A}_{0} / \mathrm{WSN}$.

The strain of Semliki Forest virus (SFV) used to assay mouse interferon was kindly supplied by Dr N. B. Finter (Wellcome Research Laboratories, Beckenham, Kent), and was grown in primary cultures of chick embryo fibroblasts.

\section{Tissue cultures and media}

Mouse fibroblast L-929 cells (Flow Laboratories Ltd, Irvine, Scotland), used for the assay of mouse interferon, were grown in Eagle's Basal Medium (Burroughs Wellcome \& Co., London) containing 10 per cent. calf serum, 0.04 per cent. sodium bicarbonate and penicillin, 100 units per ml, polymyxin B, 100 units per $\mathrm{ml}$ and streptomycin $100 \mu \mathrm{g}$ per ml. The cells were maintained in the same medium but with 2 per cent. calf serum and 0.06 per cent. sodium bicarbonate. For immunofluorescence experiments, the $L$ cells were grown on glass coverslips in petri dishes in an atmosphere of 5 per cent. $\mathrm{CO}_{2}$ in air. When confluent monolayers had formed the coverslips were transferred to $50-\mathrm{mm}$-diameter petri dishes and maintained in serum-free Medium 199 (B.D.H. Chemicals, Poole).

Primary mouse kidney cell cultures, prepared from 5-7-day-old Swiss mice, and primary cultures of chick embryo fibroblasts, prepared from 11-day-old embryos, were grown and maintained in the same medium used for L-929 cultures but supplemented with 0.3 per cent. tryptose phosphate broth.

For plaquing experiments, monolayers of mouse kidney cells or chick embryo fibroblasts were grown in $50-\mathrm{mm}$ glass petri dishes in 5 per cent. $\mathrm{CO}_{2}$ in air and, after infection, were overlayed with a mixture of equal volumes of 1.8 per cent. Ionagar no. 2 (Oxoid Ltd, London) and double-strength medium 199 containing 0.03 per cent. DEAE-dextran (Pharmacia, Uppsala, Sweden). For visualisation of the plaques, the monolayers were later covered with a second overlay containing 0.0025 per cent. neutral red but no DEAE-dextran.

Rhesus monkey kidney-cell cultures, obtained from the Medical Research Council Laboratories, Hampstead, were used to titrate influenza virus infectivity. They were grown in the same medium used for L-929 cells, and were maintained in serum-free medium 199.

\section{Titration of influenza virus infectivity}

Lungs from infected mice were homogenised with sterile sand in a mortar and resuspended to approximately 10 per cent. (w/v) in medium 199. After clarification by centrifugation at $500 \mathrm{~g}$ for $15 \mathrm{~min}$., portions of the supernatant were frozen at $-70^{\circ} \mathrm{C}$ and subsequently titrated, by the haemadsorption technique, in monkey kidney-cell cultures. The infectivity (TCD50) was calculated by the Spearman-Karber method (Dougherty, 1964).

\section{Titration of interferon}

Portions of the clarified, homogenised mouse-lung suspensions, prepared as above, were acidified with $\mathrm{M}-\mathrm{HCl}$ to $p \mathrm{H} 2$ and kept at $4^{\circ} \mathrm{C}$ for 2 days; the $p \mathrm{H}$ was then readjusted to 7 with 
$\mathrm{M}-\mathrm{NaOH}$. The treated suspensions were centrifuged at $100,000 \mathrm{~g}$ for $2 \mathrm{hr}$ and the top fourfifths of the supernatant fluid was stored, in small amounts, at $-20^{\circ} \mathrm{C}$. Interferon activity was determined by the dye-uptake (DU) method (Finter, 1969), in tests on L-929 cells, which had been aged for 4 days (McLaren, 1970), with Semliki Forest virus as the challenge virus. A standard reference interferon preparation was included in each assay. In this laboratory one DU50 unit was equivalent to $2 \cdot 75$ International Units (IU).

\section{In-vivo experiments}

Young adult Swiss mice (20-25 g) from the laboratory's own closed, randomly bred colony were used for all experiments.

Influenza virus virulence. The influenza virus strains were graded for virulence by their ability to kill or produce lung lesions in mice that had been infected intranasally under light ether anaesthesia. Groups of 14 mice were given approximately $0.05 \mathrm{ml}$ of stock virus either neat or diluted 1 in 10 or 1 in 100 in medium 199. The different virus pools all had comparable infectivity titres $\left(1-5 \times 10^{7} \mathrm{TCD} 50 \mathrm{per} \mathrm{ml}\right)$ in rhesus-monkey kidney-cell cultures, except for that of $\mathrm{A}_{2} /$ Singapore/1/57 which had a titre 50-200-fold lower than the other strains. The infected animals were examined daily, and deaths were recorded over a period of 14 days. Four animals from each group were killed after 7 days and their lungs were examined for the presence of dark purple coloured lesions.

Interferon induction by influenza viruses. Groups of 40-50 mice were infected intranasally with approximately $5 \times 10^{4}$ TCD50 of influenza virus. Four animals from each group were killed, by cervical dislocation, after $6 \mathrm{hr}$ and thereafter at 24-hr intervals for 8 days. The lungs from each batch of four mice were removed aseptically, pooled and examined for virus infectivity and interferon. Duplicate experiments were carried out at different times with strains $\mathrm{A}_{0} / \mathrm{WSN}$ and ts 19 to determine any experimental variation.

\section{In-vitro experiments: sensitivity of influenza viruses to interferon inhibition}

The mouse interferon used in the sensitivity studies was prepared from the brains of mice infected with Semliki Forest virus, by the acid treatment-ultracentrifugation method already described for influenza-infected mouse-lung preparations. The interferon pool had a titre of $2750 \mathrm{IU}$ per $\mathrm{ml}$.

Immunofluorescence reduction method. Monolayers of L-929 cells on coverslips were incubated overnight with $4 \mathrm{ml}$ of either medium 199 alone or medium 199 containing 40 DU50 of mouse interferon. The monolayers were then washed twice with Hanks' solution and covered with $4 \mathrm{ml}$ of medium 199 containing sufficient influenza virus to infect about 5 per cent. of the cells. After adsorption for $1 \mathrm{hr}$ at $36^{\circ} \mathrm{C}$, the medium was decanted and replaced with fresh medium 199. After further incubation overnight, the monolayers were fixed with acetone and stained by the indirect immunofiuorescence method, in which convalescent human serum and swine anti-human gamma-globulin conjugated with fluorescein isothiocyanate (Nordic Pharmaceuticals and Diagnostics, Tilburg) were used. They were examined under a Gillet and Sibert Conference microscope with iodine-quartz illumination. The sensitivity to interferon of the influenza virus strains was calculated as the percentage reduction in the number of cells showing specific fluorescence in the interferon-treated cultures, compared with the control, interferon-free cultures; approximately 3000 cells were counted in each culture (Oxford and Schild, 1968).

Plaque-reduction method. Monolayers of primary mouse-kidney cells in 50-mm petri dishes were incubated overnight with $3 \mathrm{ml}$ of medium 199 alone or medium 199 containing approximately 30 DU50 of mouse interferon. The cells were then washed twice with Hanks' solution and infected with suitable dilutions of influenza virus in medium 199. After adsorption for $1 \mathrm{hr}$ at $36^{\circ} \mathrm{C}$ the medium was decanted, the first agar overlay was applied and the cultures were returned to the incubator. Three to 4 days later the second, staining, overlay was added and, after a further 4-6 hours' incubation, the plaques were counted. Sensitivity to interferon was calculated as the percentage reduction in the number of plaques in the 
interferon-treated cultures, compared with the control, interferon-free cultures. When similar tests with Semliki Forest virus were included for reference purposes, the corresponding control cultures were overlayed for staining on the 2nd day after infection, since the more rapidly growing plaques of this virus became confluent on longer incubation.

Haemagglutinin-yield reduction method. Mouse kidney cell monolayers in 4-oz. medical flat bottles were incubated overnight with $10 \mathrm{ml}$ of medium 199 alone or medium 199 containing approximately 100 DU50 of mouse interferon. The cell sheets were then rinsed with Hanks' solution and covered with medium 199 containing 10-100 TCD50 of influenza virus, as calculated by titration on mouse kidney cells. After adsorption for $1 \mathrm{hr}$, the monolayers were again washed, covered with $10 \mathrm{ml}$ of fresh medium 199, and returned to the incubator. The medium was harvested $24 \mathrm{hr}$ later and replaced with fresh medium which was also harvested after a further $24 \mathrm{hr}$. The harvested fluids from duplicate cultures were pooled and titrated for haemagglutinin (HA) (WHO, 1953). Sensitivity to interferon was calculated as the percentage reduction in HA content of the interferon-treated cultures, compared with the control cultures. The whole range of influenza virus strains was tested at the same time on a single prepared batch of mouse kidney cells.

\section{RESULTS}

\section{In-vivo experiments}

Influenza virus virulence. The various strains of influenza virus differed considerably in their ability to kill and produce lung lesions in mice. Stock preparations of $\mathrm{A}_{0} / \mathrm{WSN}$ regularly killed mice when used neat (five out of ten mice) or diluted 1 in 10 (two out of ten mice); dilutions of 1 in 100 usually produced lung lesions (two out of four mice). The mutants ts4, ts7 and ts 19 were less virulent than the parent strain, since undiluted virus usually failed to kill mice and produced only small lung lesions; the latter were occasionally found with dilutions of 1 in 10 . Mutants ts 10 and ts 18 were never observed to kill animals and neat virus produced only small lung lesions; these were seen on rare occasions with virus dilutions of 1 in 10 . $\mathrm{A}_{0} / \mathrm{NWS}$ resembled ts 10 and ts 18 in virulence, while the recombinants $\mathrm{X} 7$ and $\mathrm{X} 9$ killed some animals when used neat (one out of ten) and resembled ts4, ts7 and ts19. The mouse-adapted strain of $\mathrm{A}_{2} /$ Singapore/1/57 was the most virulent of all the strains tested, killing some mice (two out of ten) and producing lung lesions in all mice at a dilution of 1 in 100 . Most of the mice dying in these various experiments did so between 5 and 8 days after infection. From the results the virus strains were graded for virulence on an arbitrary four-point scale (table I). Mackenzie (1969) has reported that mutants ts 4 and ts 10 were "completely avirulent" and that ts 7 , ts 18 and ts 19 were "attenuated" compared with $\mathrm{A}_{0} / \mathrm{WSN}$, when tested in young adult C57 B1 mice.

Interferon induction by influenza viruses. Fig. 1 illustrates the production of infective virus and interferon in the lungs of the influenza-virus infected mice. The actual titres present on days 2, 3 and 4 after infection appear to be characteristic of the individual virus strains and are shown more clearly in fig. 2.

The virulent strains $\mathrm{A}_{0} / \mathrm{WSN}$ and $\mathrm{A}_{2} /$ Singapore/1/57 generally produced higher titres of virus infectivity during the first 4 days after infection than the other strains tested. They also induced the highest interferon titres; $\mathrm{A}_{0} / \mathrm{WSN}$ infected animals had 550 DU50 per $\mathrm{ml}$ of interferon in their lungs 5 days after infection, $A_{2} /$ Singapore/1/57 infected-mice had 410 DU50 per $\mathrm{ml}$ after 
TABLE I

The virulence of influenza viruses for Swiss mice

\begin{tabular}{lc}
\hline \multicolumn{1}{c}{ Virus strain } & Measurement of virulence* \\
\hline $\mathrm{A}_{0} /$ WSN & +++ \\
ts4 & ++ \\
ts7 & ++ \\
ts10 & + \\
ts18 & + \\
ts19 & ++ \\
$\mathrm{A}_{0} / \mathrm{NWS}$ & + \\
$\mathrm{A}_{2} /$ Singapore/1/57 & +++ \\
$\mathrm{X} 7$ & ++ \\
$\mathrm{X} 9$ & ++ \\
\end{tabular}

* Graded according to ability to kill mice or produce lung lesions, after intranasal infection: $+=$ no deaths but lung lesions present, with neat virus; $++=$ deaths with neat virus, lung lesions with 1 in 10 dilution of virus; $+++=$ deaths with 1 in 10 virus, lung lesions with 1 in 100 virus; $++++=$ deaths or lung lesions with 1 in 100 virus.
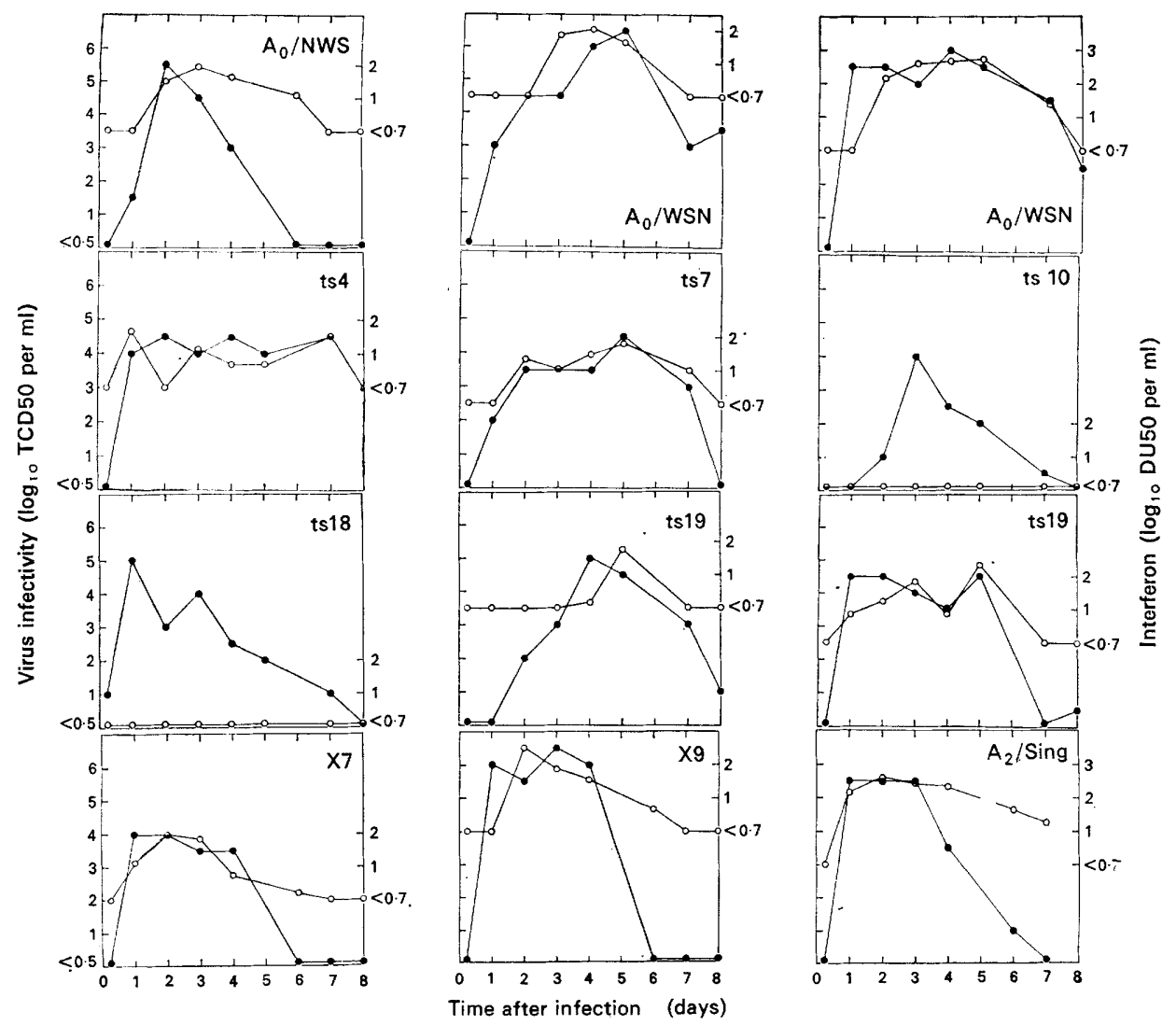

FIG. 1.-Rate of production of interferon $(0-0)$ and infectious virus $(-\bullet)$ in the lungs of mice infected with various strains of influenza virus. 
2 days. The rate of virus multiplication was usually rapid for the virulent strains, although in one experiment with $\mathrm{A}_{0} / \mathrm{WSN}$ a markedly slower rate of virus replication was observed (figs. 1 and 2). In this experiment there was also a delay in interferon production and in clearing of virus from the lungs; the total amount of interferon produced was less and there were no deaths. In the second experiment with $\mathrm{A}_{0} / \mathrm{WSN}$, in which seven mice died between days 7 and 10, the amount of virus present in the lungs of surviving animals killed on these days was found to be decreasing.

Strains ts4, ts7 and ts19 grew less well in the lungs of infected animals and produced lower levels of interferon than the most virulent strains, although duplicate experiments with ts 19 showed some variation in the rates of virus multiplication and interferon induction. Some mice infected with ts 4 and ts 7 died on the 4th day or later after infection, although virus re-isolated from

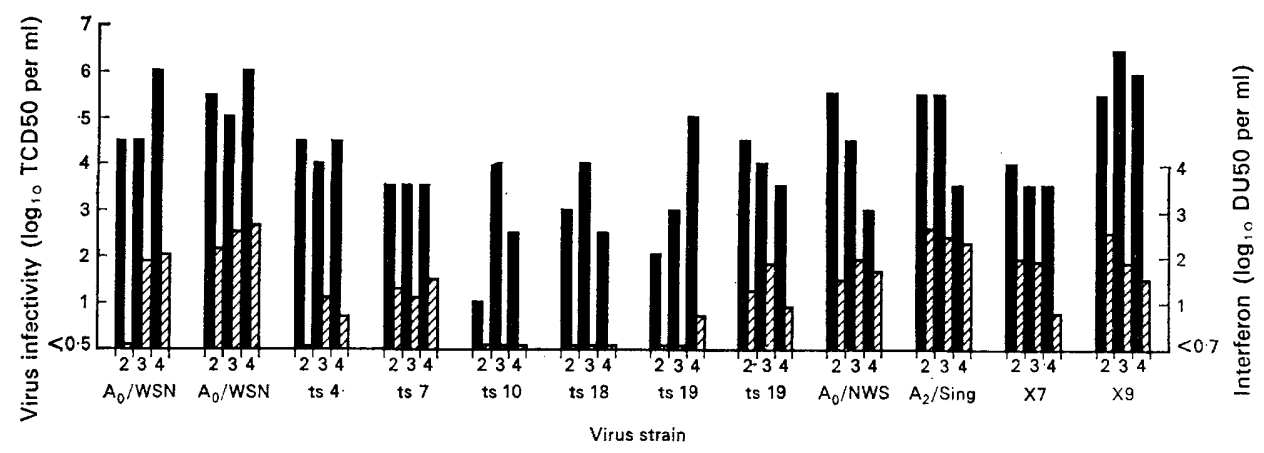

FIG. 2.-Titres of interferon (包) and infectious virus ( $\mathbf{D}$ ) in the lungs of mice 2,3 and 4 days after infection with various strains of influenza virus.

infected animals on the 5th day was found to be as temperature sensitive as the original stock strain, which had previously been found not to kill mice at the same dilution. Recombinant $\mathrm{X} 9$ grew rapidly to high titre and also produced high levels of interferon, but caused no deaths.

Strain ts10 grew relatively poorly, producing only $10^{4}$ TCD50 per ml of infective virus by the 3rd day, and no interferon was detected in the lungs of any of the infected mice. Interferon was also apparently absent from ts18infected animals, although this virus grew more rapidly and achieved higher titres than did ts10. With both $\mathrm{A}_{0} / \mathrm{NWS}$ and $\mathrm{X} 7$, moderately high titres developed but virus was then completely cleared from the lungs by the 6th day; interferon was present in moderate amounts (approximately 90 DU50 per ml). No deaths were observed with these four strains of virus at the inoculum level used for the interferon-induction experiments.

Properties of the mouse-lung interferon. The interfering activity present in two lung preparations was removed by treatment with trypsin, was stable at $37^{\circ} \mathrm{C}$ for $60 \mathrm{~min}$. and did not protect monkey kidney tissue culture cells against challenge with SFV. The methods used for the preparation and testing of all the mouse-lung samples examined showed that the interfering activity was resistant to $p \mathrm{H} 2$ for $48 \mathrm{hr}$ and was not sedimented at $100,000 \mathrm{~g}$ for $2 \mathrm{hr}$, and 
that it affected the virus indirectly, that is, through the host cells. For these reasons, it was concluded that the interfering activity was due to interferon.

It was considered that the absence of interferon activity in the lungs of ts10- and ts18-infected mice might be due to the presence of an inhibitor. A lung preparation of known interferon titre, from $\mathrm{A}_{0} / \mathrm{WSN}$-infected mice was mixed with an equal volume of a lung preparation without detectable interferon activity, from ts10-infected mice. The mixture was then titrated for interferon, in parallel with the individual lung preparations. The mixed lung preparations showed no loss of interferon activity compared with the original positive lung suspension.

Analysis of results. From the information obtained in 12 experiments, involving ten different influenza-virus strains, the arithmetic mean titres $(\bar{x})$ of

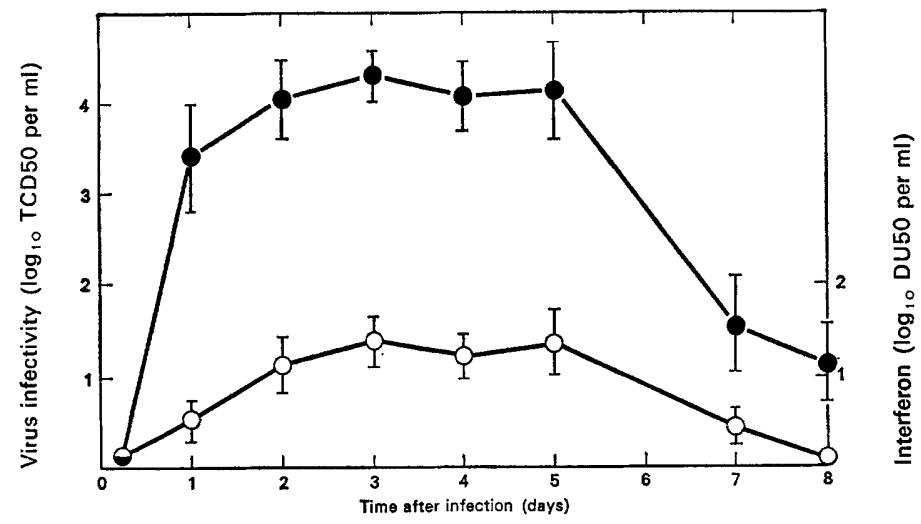

FIG. 3.-Mean titres of interferon $(\mathrm{O}-\mathrm{O})$ and infectious virus $(-\bullet)$ in the lungs of all the mice infected with different strains of influenza viruses. The standard error of the mean is indicated by the vertical lines.

interferon and of virus infectivity present in the lungs of infected mice, on each day after infection, were calculated. Because of the small sample size $(n=4)$ for the 6 th day after infection, mean values were not calculated for this day. The results are given in fig. 3 together with the standard errors for each value. These show that during the first 5 days after infection, virus infectivity and interferon levels closely paralleled each other. After the 5 th day the virus titre appeared to fall more rapidly than the interferon titre.

Regression analysis of the results from all the mouse lung experiments showed a fair degree of correlation $(r=0.61)$ between the logarithms of the virus infectivity titres and the corresponding interferon titres (fig. 4).

\section{Sensitivity of influenza viruses to inhibition by interferon in vitro}

Reduction of immunofluorescence. Infective virus was not detected in the medium from cultures of L-929 cells infected with any of the influenza viruses, but virus antigens were demonstrable in the cells by immunofluorescence. Nuclear fluorescence was obvious in control cultures $7-8 \mathrm{hr}$ after infection and 
by $18 \mathrm{hr}$ there was strong cytoplasmic, as well as nuclear, fluorescence. After $24 \mathrm{hr}$, infected cells began to round up and became detached from the coverslips.

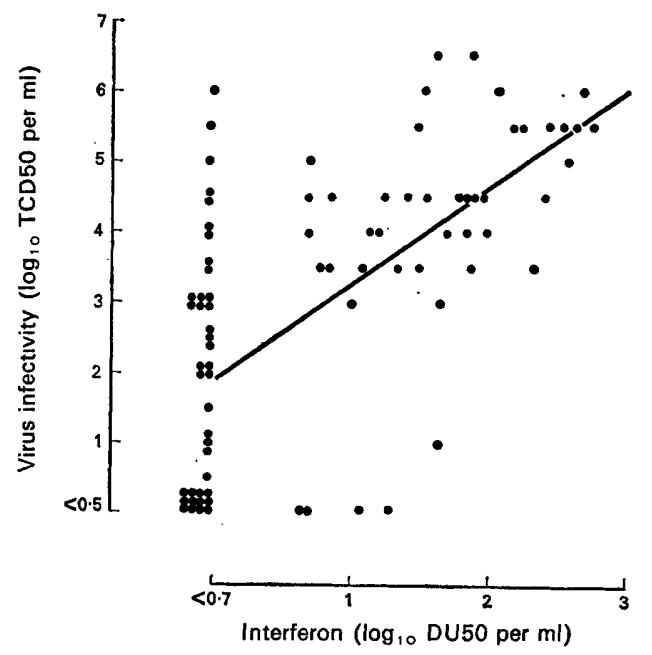

FIG. 4.-Relationship between interferon titres and virus infectivity titres in the lungs of mice infected with different strains of influenza viruses $(\mathrm{m}=1.35, \mathrm{r}=0.61)$.

TABLE II

Inhibition of influenza viruses by mouse interferon in vitro

\begin{tabular}{|c|c|c|c|}
\hline \multirow[b]{2}{*}{ Virus strain } & \multicolumn{3}{|c|}{ Percentage reduction in virus growth, measured by } \\
\hline & immunofluorescence & plaque reduction & haemagglutinin yield \\
\hline $\begin{array}{l}\mathrm{A}_{0} / \mathrm{WSN} \\
\text { ts } 4 \\
\text { ts7 } \\
\text { ts } 10 \\
\text { ts } 18 \\
\text { ts } 19 \\
\mathrm{~A}_{0} / \mathrm{NWS} \\
\mathrm{A}_{2} / \mathrm{Sing} \\
\text { X7 } \\
\text { X9 } \\
\text { Semliki Forest Virus } \\
\text { (control) }\end{array}$ & $\begin{array}{l}72 \\
68 \\
89 \\
76 \\
71 \\
84 \\
75 \\
83 \\
71 \\
71 \\
\text { NT }\end{array}$ & $\begin{array}{c}75 \\
53 \\
55 \\
60 \\
\text { NP* } \\
69 \\
83 \\
73 \\
\text { NP } \\
56 \\
93\end{array}$ & $\begin{array}{l}75 \\
88 \\
88 \\
88 \\
88 \\
88 \\
88 \\
75 \\
\text { NT } \dagger \\
\text { NT } \\
\text { NT }\end{array}$ \\
\hline
\end{tabular}

$* \mathrm{NP}=$ Failure to form plaques in mouse kidney cell cultures

$+\mathrm{NT}=$ Not tested.

Several experiments were carried out with each virus strain and the mean percentage inhibition of the different viruses affected by interferon is shown in table II. This varied from 68 per cent. for strain ts 4 to 89 per cent. for ts7, both of which had equal virulence for mice. These differences in sensitivity to interferon are probably not significant.

Experiments with primary mouse kidney-cell cultures, which do liberate 
infective virus, were discontinued because of the great variability in results, even in replicate monolayers in the same petri dish.

Plaque inhibition. The influenza virus strains varied in their ability to produce plaques in mouse kidney-cell cultures. Strains ts 18 and X7 did not form plaques, ts 7 and ts 19 produced small, ill-defined plaques approximately $1 \mathrm{~mm}$ in diameter, and the other strains formed plaques $1-2 \mathrm{~mm}$ in diameter. On the other hand, SFV readily produced plaques which were about $10 \mathrm{~mm}$ in diameter by the 3rd day after infection of the monolayers.

SFV was the most sensitive to inhibition by mouse interferon; plaque counts were reduced by as much as 93 per cent. (table II) and there was also a reduction in plaque size from $10 \mathrm{~mm}$ to $2 \mathrm{~mm}$. The results for individual influenza viruses varied from experiment to experiment. However, the mean percentage reduction in plaque count in three to five experiments carried out with the influenza virus strains is shown in table II. The different strains did not appear to differ significantly in their sensitivity to interferon, although they were all less sensitive to it than SFV. There was little or no reduction in the size of the influenza virus plaques in the interferon-treated cultures.

Reduction in $H A$ yield. The amount of HA released into the medium from mouse kidney-cell cultures, in the presence or absence of interferon, was determined $24 \mathrm{hr}$ and $48 \mathrm{hr}$ after virus infection. At the low multiplicity of infection used in these experiments, the haemagglutinin titres corresponded closely to the amounts of infectious virus liberated into the medium. At $24 \mathrm{hr}$, the amount of HA in the medium of most of the cultures was too low to allow satisfactory comparisons to be made; it was detected in only two sets of interferon-treated cultures ( $\mathrm{A}_{0} / \mathrm{WSN}$ and ts7) and was absent in two sets of control cultures (ts18 and $\mathrm{A}_{2} /$ Singapore/1/57). However, the culture fluids harvested after $48 \mathrm{hr}$ all had measurable amounts of $\mathrm{HA}$. The virus strains showed a percentage reduction in HA yield, in the presence of interferon, of between 75 and 88 per cent. (table II). Within the limits of experimental error, these differences are probably not significant, and all the viruses appear to be equally sensitive to interferon inhibition.

\section{Discussion}

The term virulence can be interpreted in a number of ways, depending on the experimental system (CIBA Foundation Study Group No. 4, 1960). We have restricted this study to a single group of viruses (influenza viruses) growing in a single host (the mouse or its cells). By using closely related mutant strains, as well as more distantly related strains, we hoped to avoid comparisons between viruses completely different in their cultural behaviour. The virulence of these strains was measured by their ability to produce lung lesions and to kill infected animals. The findings of Mackenzie (1969) were confirmed that temperature-sensitive mutant strains were less virulent for mice than the wildtype strain.

The most virulent strains, $\mathrm{A}_{0} / \mathrm{WSN}$ and $\mathrm{A}_{2} /$ Singapore $/ 1 / 57$, together with the less virulent strain $\mathrm{X} 9$, produced the most interferon and they also grew to higher titres than the other viruses. Those viruses which grew least well, ts 19 
and ts18, were the poorest inducers of interferon. These results suggest that the level of interferon induction is a reflection of virus multiplication, as proposed by Vilček (1964) and Link, Blašković and Raus (1965). Regression analysis of all the results obtained in the study confirmed the direct relationship of interferon titres to virus infectivity titres and show that in the influenza virus-mouse system virus virulence is associated with good interferon induction and not with low interferon induction, as has been reported for other systems.

While the quantities of interferon found in the lungs during the first 3-4 days of infection were generally related to the amounts of virus present, there were some exceptions. Thus, virus strains $X 7$ and ts 18 grew to reach more or less the same titre of infectivity, but X7 induced moderate amounts of interferon and ts 18 none at all. Possibly another virus-specific character is also involved. Perhaps some of the viruses are less efficient at assembling infectious particles from the pools of precursor components and require much larger amounts of viral RNA to assemble the same numbers of complete virions than do the more efficient viruses. This overproduction of RNA would provide a greatly increased stimulus to interferon production.

Since the virulence of the various strains of influenza virus did not appear to be related to the actual quantity of interferon induced, we next examined their sensitivity to inhibition by interferon. This was measured at different stages of virus production and release from infected cells. Thus, the intracellular production of viral antigens was followed by immunofluorescence, and the release of mature virions by the HA content of the culture medium, while the plaque reduction technique monitored both any suppression of intracellular infectivity and any change in the rate and amount of production of infectious virus. The different strains of influenza virus were found to be equally sensitive to interferon by all three methods, although, as a group, they proved to be more resistant to the action of interferon than SFV. Previous investigations have also shown influenza virus to be generally more resistant to interferon than other viruses (Ruiz-Gomez and Isaacs, 1963b; Hill, Baron and Chanock, 1969; Pindak, Schmidt and Kendrick, 1969; Gallagher and Khoobyarian, 1971).

The results obtained in this study fail to indicate a definite role for interferon in determining the virulence of influenza viruses for mice. The response of the host is obviously important and probably involves a complex interplay of cellular and humoral immunity mechanisms, including interferon, at different stages of the infection (Glasgow, 1970). These responses together with certain properties of the virus, such as growth rate (Kendal and Allan, 1970) and ability to suppress host cell synthesis (Wertz and Youngner, 1970), ultimately determine the virulence of a virus for its host. Thus, the expression of virulence by a single parameter, such as host death or the amount of interferon induced, may lead to an oversimplification of the concept of virulence.

\section{SUMMARY}

The virulence of influenza-virus strains for Swiss mice was compared with the amount of interferon induced by them in the lungs of the mice and with 
their sensitivity to inhibition by interferon. The virus strains examined, which included a number of temperature sensitive (ts) mutants, were graded for virulence by their ability to cause lung lesions and to kill mice after intranasal infection. The amount of interferon produced was found to be related to virus growth; the more virulent virus strains grew to higher titres and produced the most interferon. All the strains proved to be equally sensitive to interferon, by three different in-vitro techniques. It was concluded that the virulence of influenza viruses for the mouse is determined by factors other than interferon.

We wish to thank Professor Sir Charles Stuart-Harris for our valuable discussions during the course of this work, and Dr F. Ruben for his helpful comments on the manuscript. The technical assistance of Mr M. D. Denton is gratefully acknowledged. One of us (C. McL.) held a Medical Research Council Scholarship during the period of this study.

\section{REFERENCES}

Campbell, J. B., ANd Colter, J. S. 1967. Sensitivity to, and production of interferon by three variants of Mengo virus. Canad.J. Microbiol., 13, 931.

Ciba Foundation Study Group No. 4 1960. Virus virulence and pathogenicity, edited by G. E. W. Wolstenholme and Cecilia M. O'Connor, London.

Dougherty, R. M. 1964. Animal virus titration techniques. In Techniques in experimental virology, edited by R. J. C. Harris, London, p. 169.

ENDERS, J. F. 1962. Measles virus. Historical review, isolation, and behaviour in various systems. Amer. J. Dis. Child., 103, 282.

FINTER, N. B. 1964. Interferon production and sensitivity of Semliki Forest virus variants. J. Hyg., Camb., 62, 337.

FiNTER, N. B. 1969. Dye uptake methods for assessing viral cytopathogenicity and their application to interferon assays. J. Gen. Virol., 5, 419.

Gallagher, J. G., and Khoobyarian, N. 1971. Sensitivity of adenovirus types, 1, 3, 4, 5, 8, 11 and 18 to human interferon. Proc. Soc. Exp. Biol. Med., 136, 920.

GLASGOW, L. A. 1970. Interrelationships of interferon and immunity during viral infections. J. Gen. Physiol., 56, 212s.

Hill, D. A., Baron, S., AND Chanock, R. M. 1969. Sensitivity of common respiratory viruses to an interferon inducer in human cells. Lancet, 2, 187.

Kendal, A. P., AND Allan, W. H. 1970. Comparative studies of Newcastle disease viruses. I. Virulence, antigenic specificity and growth kinetics. Microbios, 2, 273.

Kilbourne, E. D., Lief, Florence S., Schulman, J. L., Jahiel, R. I., and Laver, W. G. 1967. Antigenic hybrids of influenza viruses and their implications. In Perspectives in virology, edited by M. Pollard, London, vol. 5, p. 87.

LINK, F., BLAŠKović, D., AND RaUS, J. 1965. Relationship between virus multiplication and interferon production in mouse lungs after infection with adapted and unadapted influenza viruses. Acta Virol., Prague, 9, 95.

LOMNICZI, B. 1970. Systemic induction of interferon in chicks with various NDV strains. I. Relationship between virulence of the virus and the mechanism of interferon production. Arch. ges. Virusforsch., 30, 159.

MACKenZIE, J. S. 1969. Virulence of temperature-sensitive mutants of influenza virus. Br. Med. J., 3, 757.

MACKENZIE, J. S. 1970. Isolation of temperature-sensitive mutants and the construction of a preliminary genetic map for influenza virus. J. Gen. Virol., 6, 63.

MCLAREN, C. 1970. Influence of cell age on production and assay of mouse interferon in L-cells. Arch. ges. Virusforsch., 32, 13.

MAEYER, E. DE, AND ENDERS, J. F. 1965. Growth characteristics, interferon production and plaque formation with different lines of Edmonston measles virus. Arch. ges. Virusforsch., 16, 151. 
MIRCHAMSY, H., AND RAPP, F. 1969. Role of interferon in replication of virulent and attenuated strains of measles virus. J. Gen. Virol., 4, 513.

OXFORD, J. S., AND SCHILD, G. C. 1968. Immunofluorescent studies on the inhibition of influenza A and B viruses in mammalian cell cultures by amines and ammonium compounds. J. Gen. Virol., 2, 377.

PINDAK, F. F., SCHMIDT, J. P., AND KendRICK, J. Z. 1969. Influence of statolon on resistance of mice to influenza. Appl. Microbiol., 18, 147.

Postic, B., Schleupner, C. J., Armstrong, J. A., AND Ho, M. 1969. Two variants of Sindbis virus which differ in interferon induction and serum clearance. I. The phenomenon. J. Infect. Dis., 120, 339.

RoKUTANDA, H. K. 1969. Relationship between viremia and interferon production of Japanese encephalitis virus. J. Immun., 102, 662.

RUIZ-GOMEZ, J., AND ISAACS, A. 1963a. Interferon production by different viruses. Virology, 19, 8.

RuIz-Gomez, J., AND IsaACs, A. 1963b. Optimal temperature for growth and sensitivity to interferon among different viruses. Virology, 19, 1.

SELLERS, R. F. 1963. Multiplication, interferon production and sensitivity of virulent and attenuated strains of the virus of foot-and-mouth disease. Nature, Lond., 198, 1228.

VILČEK, J. 1964. Production of interferon by newborn and adult mice infected with Sindbis virus. Virology, 22, 651.

Wertz, GaIl W., AND Youngner, J. S. 1970. Interferon production and inhibition of host synthesis in cells infected with vesicular stomatitis virus. J. Virol., 6, 476.

World Health Organization 1953. Expert Committee on Influenza. First report. World Health Organization Technical Report Series no. 64. 